\title{
A Bizonytalanságintolerancia Skála rövidített változatának magyar nyelvứ adaptációja
}

\author{
ZSIDÓ N. ANDRÁS* - ARATÓ NIKOLETT - INHÓF ORSOLYA - \\ BUDAI TIMEA - STECINA T. DIÁNA - LABADI BEATRIX
}

Pécsi Tudományegyetem, Pszichológia Intézet, Pécs

(Beérkezett: 2020. augusztus 12.; elfogadva: 2021. január 5.)

Bevezetés: A bizonytalanságintolerancia egy egyén alapvető képtelenségét jelenti a negatív események előfordulásának, valamint az ilyen események be nem jósolhatóságának elviselésére. Az ebből fakadó állandósult stressz és túlzott aggodalom súlyos fizikai és mentális problémákhoz vezethet. Korábbi tanulmányok eredményei szerint a jelenség a szorongásos és a depresszív pszichiátriai zavarok alapja lehet. Célkitüzés: A jelen tanulmány célja a Bizonytalanságintolerancia Skála rövidített változatának pszichometriai elemzése egy megfelelően nagy és az életkor szempontjából diverz magyar anyanyelvú mintán. Módszer: A keresztmetszeti kutatás keretében összesen 1297 fö (300 férfi és 993 nő, 4 fő nem válaszolt) töltötte ki a kérdőívcsomagot. A résztvevők átlagéletkora 44,6 év (SD = 22,44 év; terjedelem: 18-83 év). A rövidített Bizonytalanságintolerancia Skála mellett a résztvevők kitöltötték a World Health Organization Jól-lét Indexet, valamint a Beck Depresszió Leltár és a Spielberger-féle Vonásszorongás Skála rövidített változatát. A Bizonytalanságintolerancia Skála pszichometriai mutatóit klasszikus és modern tesztelméleti módszerekkel is ellenőriztük. Eredmények: A Bizonytalanságintolerancia Skála megfelelő pszichometriai mutatókkal rendelkezik a vizsgált magyar mintán (McDonald- $\omega=0,82$ és 0,84). A kérdőív tételei jól diszkriminálnak a látens változó különböző szintjeivel rendelkező kitöltők között, és a kérdőív összességében megbízhatóan mér meglehetősen nagy szórástartományban ( \pm 2 szórás); tehát a bizonytalanságtûrés képességéről a populáció hozzávetőlegesen 95\%-án képes információt szolgáltatni. A kérdőív skálái és összpontszáma az elvártak szerint összefüggést mutatnak rokon konstruktumokkal, mint pl. szorongás $(r=0,22-0,36 ; p<0,001)$ és depresszió $(r=0,26-0,40 ; p<0,001)$. Következtetések: Összességében a Bizonytalanságintolerancia Skála rövid változata magyar mintán is megbízható és érvényes kérdőív. Alkalmazható lehet a mentális egészség fejlesztése, a szorongás és a depresszió prevenciójára, valamint terápiás hatékonyságvizsgálat során is.

Kulcsszavak: bizonytalanságtúrés, Bizonytalanságintolerancia Skála, IUS, pszichometriai elemzés, szorongás, depresszió

\footnotetext{
* Levelező szerző: dr. Zsidó N. András, Pécsi Tudományegyetem, Pszichológia Intézet, 7624 Pécs, Ifjúság útja 6. E-mail: zsido.andras@pte.hu
} 


\section{Elméleti háttér}

A bizonytalanságintolerancia az egyén túlzott reakciója olyan negatív helyzetekben, amikor nem áll a rendelkezésére elég és jól körülhatárolt információ a helyzet kimenetével kapcsolatban (Carleton, 2016). Vagyis intolerancia a negatív események előfordulásával, és azzal szemben, hogy nincs egyértelmú (és biztos) módszer az ilyen események előrejelzésére (Carleton, Sharpe, \& Asmundson, 2007). Továbbá, azok a személyek, akik rosszul túrik a bizonytalanságot, hajlamosabbak az ambivalens szituációkat is fenyegetőnek értékelni (Dugas és mtsai, 2005). A fenyegető ingerekre való érzékenység és fokozott válaszkészség (egy bizonyos szintig) - pl. a fenyegetó ingerek gyors detektálása - evolúciós szempontból adaptívnak tekinthetőek, hiszen a túlélést és ezáltal a reproduktív sikerességet segítik elő (Bereczkei, 2000; Zsido, 2019). A túléléshez szükséges szabályozási funkciókat (mint például a védekezés, az energia-, a hő- és a vízháztartás szabályozása, valamint a reprodukció) agyi hálózatok, az ún. túlélési körök (survival circuits) biztosítják. Különbözó ingerek más és más köröket aktiválnak (LeDoux, 2012; LeDoux \& Daw, 2018). Ha az észlelőrendszer valamilyen fenyegetéssel kapcsolatos inger jelenlétét érzékeli, az idegrendszer a defenzív kört (defensive circuit) aktiválja ${ }^{1}$, amelynek hatására különböző előre kódolt viselkedéses (pl. küzdj vagy menekülj - flight or fight - reakció), szubjektív érzelmi (pl. agresszió, félelem), és fiziológiai (pl. gyorsuló szívmúködés, illetve légzés, emelkedő vérnyomás) változások idéződnek elő a szervezetben (LeDoux, 2012). Ezek a változások együttesen teszik lehetôvé, hogy a személy megfeleló módon reagáljon a fenyegető helyzetre, ezzel növelve a túlélés valószínúségét. Ez a folyamat időnként költséges a szervezet számára, ugyanis téves riasztással járhat - pl. a személy azt hiszi, hogy egy kígyót lát, pedig csak egy gally látszik ki az avar alól -, de a téves riasztás még mindig jobb, mint ha a veszély készületlenül érné az organizmust (Marks \& Nesse, 1994; Nesse, 2005). Ugyanakkor a túlságosan érzékeny defenzív kör egyfajta állandó készenléthez, tartós stresszhez vezethet, amelynek következtében a védekezési mechanizmus egy idő után kimerül (Selye, 1946).

A bizonytalanságintolerancia és az ambivalens szituációk fenyegetőként való megélése túlzott aggodalomban és tartós szorongásban is megnyilvánulhat (Buhr \& Dugas, 2002; Ouellet, Langlois, Provencher, \& Gosselin, 2019). Ennek, valamint a környezet veszélyesként való megítélése következtében a bizonytalanság intoleranciája különböző fizikai (szomatikus) és mentális problémákhoz is vezethet (Brosschot, Verkuil, \& Thayer, 2018,

\footnotetext{
1 A humán agyi képalkotó vizsgálatok eredményei elsődlegesen az amygdala és a mediális prefrontális kéreg szerepét emelik ki a defenzív kör kapcsán (LeDoux \& Daw, 2018).
} 
2015). Egy korábbi kutatás során (Greco \& Roger, 2003) azt találták, hogy a magas bizonytalanságintoleranciával rendelkező személyek szisztolés és diasztolés vérnyomása jobban megemelkedett egy lehetséges fenyegetó helyzet bekövetkezte előtti várakozási időszakban, mint azon személyeké, akik jobban tolerálják a bizonytalan helyzeteket. Továbbá a bizonytalanságintolerancia következményeként kialakult elnyújtott stresszreakció komolyabb krónikus megbetegedések kialakulását valószínúsítheti, mint amilyen például a hipertónia, a vese-rendellenesség, a gyomorfekély, az asztma, a reumás megbetegedések vagy az inszomnia (Selye, 1946, 1951). A pszichés problémákat tekintve a bizonytalanságintoleranciát összefüggésbe hozták többek között a generalizált szorongásos zavarral (Holaway, Heimberg, \& Coles, 2006; Yook, Kim, Suh, \& Lee, 2010), az obszesszívkompulzív zavarral (Holaway és mtsai, 2006), a pánikzavarral (Carleton, Mulvogue és mtsai, 2012), a major depresszióval (Yook és mtsai, 2010), és a viselkedéses függőségekkel (Rozgonjuk és mtsai, 2019; Tiego és mtsai, 2019). Számos szerző transzdiagnosztikai tényezőként említi a bizonytalanságintoleranciát a szorongásos zavarok és a depresszió esetében (Carleton, Mulvogue és mtsai, 2012; Jensen, Cohen, Mennin, Fresco, \& Heimberg, 2016; McEvoy \& Mahoney, 2012; Strout és mtsai, 2018). Mindezek következtében a bizonytalanságintolerancia gyors kérdőíves mérése és a jelenség pontosabb megismerése a jövőbeli kutatások és a klinikai gyakorlat számára egyaránt hasznos lehet.

Az első méróeszközt a bizonytalanságintolerancia mérésére - a túlzott aggodalom kapcsán - több mint 25 évvel ezelőtt dolgozták ki (Freeston, Rhéaume, Letarte, Dugas, \& Ladouceur, 1994). Az eredeti Bizonytalanságintolerancia Skála (Intolerance of Uncertainty Scale; IUS) 27 állítást tartalmaz, amelyek az ambivalens szituációkra adott érzelmi, kognitív és viselkedéses reakciókat, valamint a bizonytalanság implikációit és a jövő kontrollálására tett erőfeszítéseket mérik ${ }^{2}$. A 12 tételes rövidített verziót (IUS-12) 2007-ben dolgozták ki (Carleton, Norton, \& Asmundson, 2007). Az IUS-12 erős lineáris kapcsolatot mutat az eredeti verzióval (Khawaja \& Yu, 2010) és más bizonytalanságintoleranciát mérő kérdőívekkel is (Fergus, 2013). Az IUS-12 két alskálát tartalmaz (Carleton, Norton és mtsai, 2007; Fergus, 2013; McEvoy \& Mahoney, 2012), úgymint prospektív szorongás - vagyis félelem és szorongás a jövőbeli események kapcsán - (pl. Ki nem állhatom a meglepetéseket.) és gátló szorongás - vagyis a cselekvést vagy megtapasztalást gátló bizonytalanság - (pl. Amikor eljön a cselekvés ideje, a bizonytalanság megbénít.).

\footnotetext{
2 Az 27 tételes verzió magyarra fordítását a dr. Faragó Klára által az ELTE PPK Pszichológiai Intézetében vezetett kutatómúhely végezte. Legjobb tudomásunk szerint az adaptáció nem került publikálásra, a magyar verzió egy doktori disszertációban érhetó el (Radnóti, 2014). Az IUS-12 magyar verziójának létrehozásakor ezt vettük alapul.
} 
Korábbi tanulmányok eredményei alapján a két alskála mellett használható a kérdőív összesített pontszáma is, mivel a kérdőívnek egydimenziós látens struktúrája van (Carleton, Weeks és mtsai, 2012). Az összpontszám és az alskálák is jó konstruktum- és diszkriminatív validitást mutattak, valamint a konvergens validitását is igazolták agorafóbiát, túlzott aggodalmat, szociális szorongást, obszesszív-kompulzív zavart, depressziót és neuroticizmust mérő kérdőívek segítségével (Carleton, Norton és mtsai, 2007; McEvoy \& Mahoney, 2012). Az IUS rövidített változatának elónye - más rövid skálákhoz hasonlatosan -, hogy gyorsabban kitölthetó, pl. a zsúfolt klinikai helyzetben, és hosszabb kutatási protokollokba is könnyebben beilleszthetó. Továbbá számos olyan speciális populáció vizsgálatakor is fontos lehet, ahol hosszabb kérdőívek kitöltése közben felmerülhet a fáradás és fókuszvesztés (Balsamo, Cataldi, Carlucci, \& Fairfield, 2018; Mueller és mtsai, 2015), mint pl. időskor, különböző (neuro)kognitív zavarok és agysérülés esetében. Az IUS-12 rövidített skála további előnye, hogy az eredeti verzióval szemben nem tartalmaz a generalizált szorongásos zavarra és a túlzott aggodalomra specifikus állításokat, így általánosabb és függetlenebb képet ad a bizonytalanságintoleranciáról (Gentes \& Ruscio, 2011).

A jelen tanulmány elsődleges célja a Bizonytalanságintolerancia Skála rövidített változata pszichometriai mutatóinak bemutatása egy megfelelően nagy és az életkor szempontjából változatos magyar anyanyelvú mintán, alkalmazva a klasszikus és a modern tesztelmélet módszereit is. További célunk volt bemutatni a kérdőívvel mért konstruktum összefüggését az életkorral, valamint bemutatni a nemi sztenderdeket.

\section{Módszer}

\subsection{Résztvevők és eljárás}

A keresztmetszeti kutatásban összesen 1297 fő (300 férfi és 993 nő, 4 fó nem válaszolt) vett részt önkéntes alapon. A résztvevők átlagéletkora 44,63 év (szórás = 22,44 év; terjedelem: 18-83 év). Hozzáférhetőségi mintavétel alkalmazásával a résztvevőket különböző korosztályokat megszólító internetes fórumokon (pl. Index, Szenior Akadémia Program) és egyetemi levelezőlistákon keresztül toboroztuk, a válaszokat a Google Forms segítségével gyújtöttük be, anonim módon. A kutatást az Egyesült Pszichológiai Kutatásetikai Bizottság hagyta jóvá (hivatkozási szám: 2020-51), és a World Medical Association etikai kódexével (Helsinki Nyilatkozat ${ }^{3}$ ) összhangban végeztük el.

3 Letöltve: 2020. 10. 16-án: https:// www.wma.net/wp-content/uploads/2016/11/HungarianDoH-2013.pdf 


\subsection{Mérőeszközök}

A kutatás elsődleges célja a Bizonytalanságintolerancia Skála (Intolerance of Uncertainty Scale; IUS) rövidített változatának (Carleton, Norton és mtsai, 2007) hazai adaptációja volt. Az IUS kérdőív rövid változata 12 állítást tartalmaz, amelyeket 5-fokú Likert-típusú skálán értékelnek a kitöltők. A kérdőívnek két skálája van: prospektív szorongás (1., 2., 4., 5., 8., 9. és 11. tétel) és gátló szorongás (3., 6., 7., 10. és 12. tétel). Az állítások egyenes irányúak, a skálák összpontszáma a tételekre kapott pontok összeadásával kapható meg. A kutatások során gyakran használják a kérdőív összpontszámát is.

A kérdőív adaptálásának folyamata követte az APA (American Psychological Association, 2010) ajánlásait. Az angolról magyarra fordítást két okleveles pszichológus végezte. Ezután egy harmadik személy, a tesztfejlesztés szakértője, összehasonlította a két verziót, és egyesíttette óket. Ezt követően egy okleveles pszichológus ezt a verziót visszafordította angolra. Végül egy pszichológusokból álló szakértői testület áttekintette a visszafordított változatot; felülvizsgálták és kijavították azt, hogy tartalmát, illetve jelentését tekintve a lehető legközelebb legyen az eredeti kérdőívhez. Az IUS kérdőív magyar változatát és kiértékelési útmutatóját a Függelék tartalmazza.

Az IUS-12 mellett, a validitásvizsgálat céljából, felvételre került még több mérőeszköz, amelyek a pszichológiai jóllétet, valamint a depressziós és a szorongásos tüneteket mérik.

A pszichológiai jóllét mérésére a World Health Organization Jól-lét Index 5-tételes változatát (WBI-5) használtuk (Susánszky, Konkoly Thege, Stauder, \& Kopp, 2006; Topp, Østergaard, Søndergaard, \& Bech, 2015). A kérdőív a kitöltő általános közérzetéről nyújt információt. A kitöltők 4-fokú, Likerttípusú skálán az egyáltalán nem jellemző (0) és a teljesen jellemző (3) végpontok között értékelik az állításokat, amelyek között nincs fordított tétel. A kérdőíven maximálisan 15 pont érhető el, és a magasabb pontszám pozitívabb pszichológiai állapotot jelez. A kérdőív megbízhatóan mért a jelen kutatásban részt vevők csoportján (McDonald- $\omega=0,88$ ).

A depressziós tüneteket a Beck Depresszió Leltár (BDI) rövidített, 6-tételes változatával (Blom, Bech, Högberg, Larsson, \& Serlachius, 2012; Rózsa, Szádóczky, \& Füredi, 2001) mértük. A kérdőív a depresszió hat specifikus tünetének jelenlétét méri fel, úgymint a szomorúság érzése, a büntudat érzése, ingerlékenység, döntésképtelenség, fáradtságérzés és munkaképtelenség. A kitöltő́k minden tünet esetében 4 állítás közül választják ki a rájuk leginkább jellemzőt (pontozás 0-3-ig), amelyek között nincs fordított tétel. A kérdőíven maximálisan 18 pont érhető el, a magasabb pontszám több depressziós tünet meglétére utal. A kérdőív a jelen kutatásban részt vevők csoportján elfogadható megbízhatósági mutatóval rendelkezett (McDonald- $\omega=0,72$ ). 
A szorongás mérésére a Spielberger-féle Vonásszorongás Skála (STAI) 5-tételes rövid változatát használtuk (Zsido, Teleki, Csokasi, Rozsa, \& Bandi, 2020). A kérdőív a szorongásra való általános hajlamot méri. A kitöltők 4-fokú, Likert-típusú skálán az egyáltalán nem jellemző (1) és a nagyon/teljesen jellemző (4) végpontok között értékelik az állításokat, amelyek között nincs fordított tétel. A skálán maximálisan 20 pont érhetô el és a magasabb pontszám magasabb vonás jellegú szorongásra utal. A jelen kutatásban részt vevők csoportján a kérdőív megbízhatóan mért (McDonald- $\omega=0,86$ ).

\subsection{Statisztikai elemzés}

Az IUS-12 kérdőív alskáláinak szerkezetét és pszichometriai tulajdonságait első lépésben a valószínúségi tesztelmélet (item response theory; IRT) módszereivel vizsgáltuk, elsősorban a mirt $\mathrm{R}$ csomag segítségével (Chalmers, 2012). Az osztályozott válaszmodellt (graded response model; GRM) (Samejima, 1968) használtuk az egyes elemek pszichometriai tulajdonságainak vizsgálatához. A GRM lehetővé teszi, hogy a tételek differenciálisan kapcsolódjanak a látens változóhoz, így becslést ad a tétel diszkriminációs (a) és nehézségi (b) paramétereire vonatkozóan. Az a paraméter megmutatja, hogy az adott tétel mennyire szorosan kapcsolódik a látens változóhoz, míg a $b$ paraméter azt jelzi, hogy a látens kontinuumon hol történik a diszkrimináció (Baker, 2001). Az a paraméter értéke 0,65 és 1,34 között közepes, 1,35 és 1,69 között magas, 1,7-től kezdődően pedig nagyon magas diszkriminációs képességre utal. Ezen felül kiszámoltuk a tétel információs görbét (item information function; IIF) minden tételre, valamint a teszt információs görbét (test information function; TIF) mindkét skálára vonatkozóan. Ezek a tételek és a skálák megbízhatóságára utalnak.

Mivel az IRT módszer megköveteli a használt skálák unidimenzionalitását, ezért ellenőriztük az IUS kérdőív eredeti faktorstruktúrájának illeszkedését a hazai mintán. Ezt megerősítő faktoranalízissel végeztük az átlósan súlyozott legkisebb négyzetek (diagonally weighted least squares; DWLS) becslóeljárással, követve az ajánlást ordinális változók esetére (Li, 2016). Korábbi kutatások szerint az IUS-12 két alfaktorból áll, ugyanakkor mivel gyakran használják az összesített pontszámot is, ezért a két faktorból álló másodrendú faktort is feltételeztük az elemzés során. A modell illeszkedésének értékeléséhez az összehasonlító illeszkedési mutatót (comparative fit index; CFI), Tucker-Lewis-indexet (TLI), a közelítés négyzetes középérték-hibáját (root mean square error of approximation; RMSEA) és a standardizált gyök-átlag négyzet maradványindexet (standardized root mean squared residual; SRMR) használtuk. A megfelelő modellilleszkedés 
határértékei a legalább 0,95-ös CFI- és TFI-értékek (Hu \& Bentler, 1998), és legfeljebb 0,08-as RMSEA és SRMR (Browne \& Cudeck, 1992) voltak. A statisztikai elemzéshez a JASP (JASP Team, 2019) statisztikai programot használtuk.

A skálák belső megbízhatóságának becslésére McDonald-féle ómegát számítottunk (McDonald- $\omega$ ). Ennek hátterében az állt, hogy a Cronbach-féle alfához képest a McDonald- $\omega$ a belső konzisztencia pontosabb mérését teszi lehetóvé, amikor a tau-ekvivalens modell előfeltétele (a valódipontszámszórás minden elemben állandó) nem teljesül (Dunn, Baguley, \& Brunsden, 2014). A konstruktum validitás ellenőrzésére Pearson-féle korrelációs eljárással vizsgáltuk az IUS-12 és a többi kérdőív közötti együttjárás mértékét. Szintén Pearson-féle korrelációval vizsgáltuk a bizonytalanságintolerancia és életkor esetleges összefüggését. Továbbá, független mintás $t$-próbával vizsgáltuk az esetleges nemi különbséget a bizonytalanságintolerancia mentén. A nemek közötti különbségek hatásméretének becslésére Cohen- $d$ mutatót számítottunk.

\section{Eredmények}

\subsection{Megerősítő faktorelemzés}

A kétfaktoros, másodrendú faktort is tartalmazó modell megfelelő illeszkedést mutatott a mintán $(\mathrm{CFI}=0,974$; TLI =0,967; RMSEA =0,075, RMSEA $\left.\mathrm{CI}_{90}=0,069-0,082 ; \mathrm{SRMR}=0,068\right)$. A faktorsúlyok a prospektív szorongás alskálán 0,49 és 0,73, míg a gátló szorongás alskálán 0,66 és 0,75 közé estek. Ezen kívül mind a prospektív, mind a gátló szorongás skála jó belső konzisztenciát mutatott (McDonald- $\omega=0,82$ és 0,84), és korrigált tétel-totál korrelációs tartomány 0,50-0,63 közötti a prospektív szorongás és 0,55-0,70 közötti a gátló szorongás skála esetében.

\subsection{Valószínúségi tesztelméleti elemzés}

Az a paraméter értékei a prospektív szorongás skálán 1,33 és 2,13 között mozogtak, míg a gátló szorongás skálán 1,45 és 2,87 között voltak, ami azt mutatja, hogy a két skála elemei többnyire magas (1., 2., 5., 9. és 3., 12. tételek) vagy nagyon magas (8., 12. és 6., 7., 10. tételek) diszkriminációs értékekkel rendelkeznek, az ajánlott küszöbértékek alapján. Egyedül a prospektív skála 4. tétele képez ez alól kivételt, de ez az állítás is közepes $a$-értékkel rendelkezett. A pontos $a$-értékeket az 1. táblázat mutatja tételenként. 
1. táblázat. A valószínúségi tesztelmélet, osztályozott válaszmodellel kapott diszkriminációs $(a)$ értékek (sztenderd hibával) tételenként a Bizonytalanságintolerancia Skála két alfaktorán

\begin{tabular}{|l|c|c|}
\hline \multirow{4}{*}{ Skála } & A tétel száma & $\begin{array}{c}\text { a-érték } \\
\text { (std hiba) }\end{array}$ \\
\hline Prospektív szorongás & 1 & $1,50(0,09)$ \\
\cline { 2 - 3 } & 2 & $1,45(0,09)$ \\
\cline { 2 - 3 } & 4 & $1,33(0,08)$ \\
\cline { 2 - 3 } & 5 & $1,45(0,09)$ \\
\cline { 2 - 3 } & 8 & $2,10(0,12)$ \\
\cline { 2 - 3 } & 9 & $1,52(0,09)$ \\
\hline Gátló szorongás & 11 & $2,13(0,12)$ \\
\hline \multirow{5}{*}{} & 3 & $1,45(0,08)$ \\
\cline { 2 - 3 } & 6 & $2,87(0,17)$ \\
\cline { 2 - 3 } & 7 & $2,71(0,15)$ \\
\cline { 2 - 3 } & 10 & $2,64(0,15)$ \\
\cline { 2 - 3 } & 12 & $1,46(0,09)$ \\
\hline
\end{tabular}

A tétel információs görbék (IIF) minden tétel esetén mutatják, hogy milyen képességi szinten a legmagasabb a tétel információtartalma a látens képességről. A görbék jól mutatják, hogy a tételek a látens változó széles skáláját fedik le. Összességében a látens képességi pontok átlaga körülbelül 0, a szórás pedig körülbelül 2. A teszt információs görbék (TIF) megközelítőleg normális eloszlást követnek. Tehát a kérdőív a populációra jellemző átlagos bizonytalanságtűrési szint kétszeres szórásán belül megbízhatóan mér. Az 1. ábra mutatja a TIF és IIF görbéket.

\subsection{A kérdőív validitása}

A Pearson-féle korrelációs elemzések eredménye szerint a prospektív- és gátló szorongás skálák, valamint az IUS-12 összesített pontszáma is szignifikáns összefüggést mutat a WBI-5, BDI és STAI skálák pontszámaival. A korrelációs együtthatók értékei a gyenge és a közepes tartományban mozognak. A 2. táblázat mutatja a pontos statisztikai értékeket. 


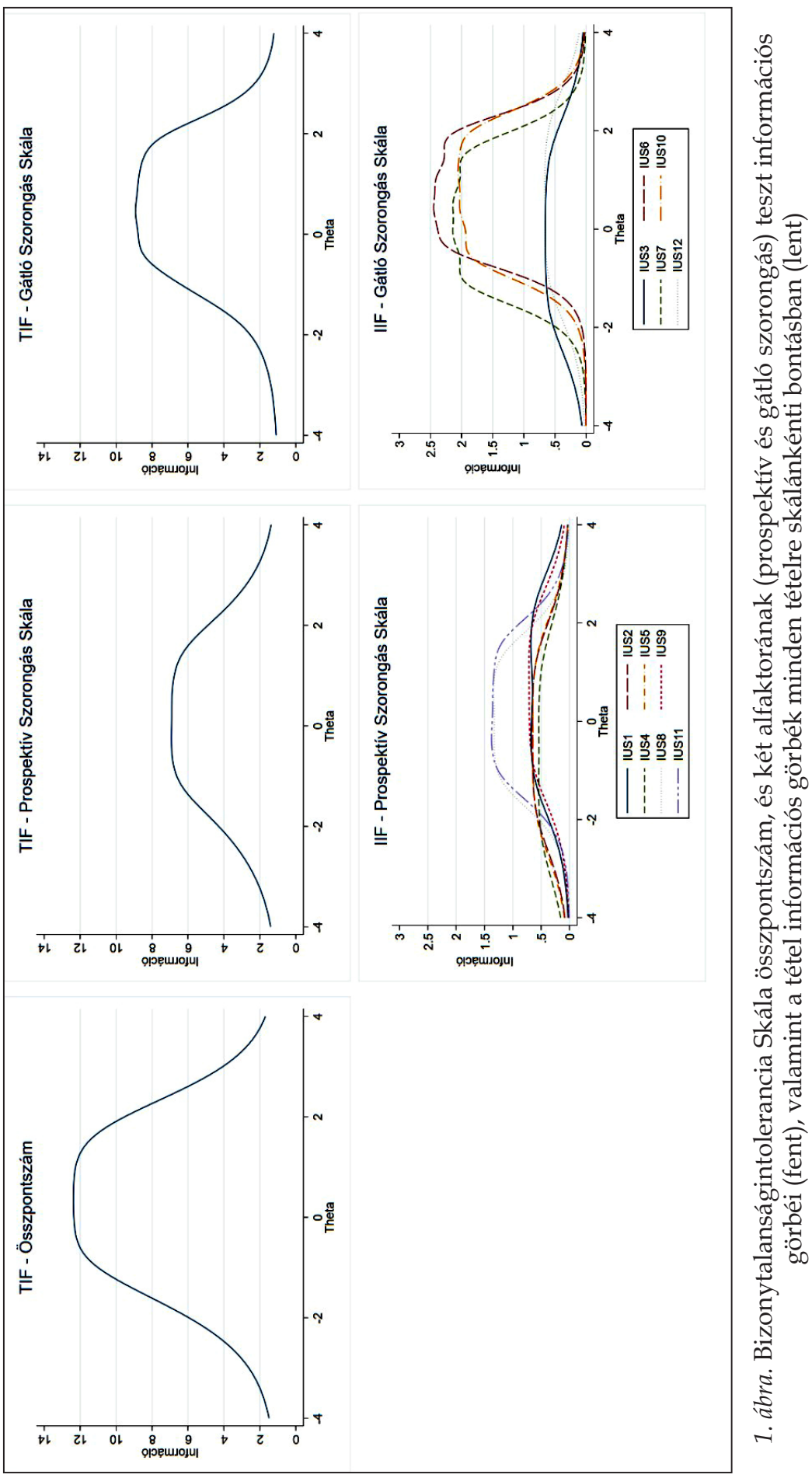


2. táblázat. A Pearson-féle korrelációs elemzések eredménye a Bizonytalanságintolerancia Skála (IUS-12) összpontszáma, és két alfaktora (prospektív és gátló szorongás) és a Jól-lét Index (WBI-5), a Beck Depresszió Leltár (BDI) és a Spielberger-féle Vonásszorongás Skála (STAI) pontszámai között

\begin{tabular}{|l|c|c|c|c|}
\hline \multicolumn{1}{|c|}{ Skála } & & $\begin{array}{c}\text { IUS-12 } \\
\text { összpontszám }\end{array}$ & $\begin{array}{c}\text { Prospektív } \\
\text { szorongás }\end{array}$ & Gátló szorongás \\
\hline \multirow{2}{*}{ WBI-5 } & $r$ & $-0,29$ & $-0,22$ & $-0,32$ \\
\cline { 2 - 5 } & $p$ & $<0,001$ & $<0,001$ & $<0,001$ \\
\hline \multirow{2}{*}{ BDI } & $r$ & 0,34 & 0,26 & 0,40 \\
\cline { 2 - 5 } & $p$ & $<0,001$ & $<0,001$ & $<0,001$ \\
\hline \multirow{2}{*}{ STAI } & $r$ & 0,30 & 0,22 & 0,36 \\
\cline { 2 - 5 } & $p$ & $<0,001$ & $<0,001$ & $<0,001$ \\
\hline
\end{tabular}

Megjegyzés: A BDI és a STAI kérdőívek esetében azok rövidített, 6-, illetve 5-tételes változatával dolgoztunk.

\subsection{Demográfiai elemzés}

Az IUS-12 összpontszám $(r=-0,11 ; p<0,001)$, a prospektív $(r=-0,07$; $p=0,010)$, és a gátló szorongás skálák $(r=-0,15 ; p<0,001)$ egyaránt igen gyenge, negatív irányú korrelációt mutattak az életkorral.

A nők szignifikánsan magasabb pontszámot értek el az IUS-12 összpontszám $(t(1291)=2,73 ; p=0,006$; Cohen- $d=0,18)$ és a gátló szorongás skála esetében $(t(1291)=4,24 ; p<0,001$; Cohen- $d=0,28)$, mint a férfiak. A prospektív szorongás esetében nem találtunk szignifikáns nemi különbséget $(t(1291)=1,24 ; p=0,214 ;$ Cohen- $d=0,08)$. A 3. táblázat szemlélteti a kérdőíven és skálákon elért átlagos pontszámokat.

3. táblázat. Bizonytalanságintolerancia Skála (IUS-12) összpontszáma, és a két alfaktorán (prospektív és gátló szorongás) elért átlagos pontszámok a teljes mintára és nemi bontásban

\begin{tabular}{|l|c|c|c|c|c|c|c|c|c|}
\hline \multirow{2}{*}{} & \multicolumn{2}{|c|}{ IUS-12 összpontszám } & \multicolumn{2}{c|}{ Prospektív szorongás } & \multicolumn{3}{c|}{ Gátló szorongás } \\
\cline { 2 - 10 } & Férfi & Nó & $\begin{array}{c}\text { Teljes } \\
\text { minta }\end{array}$ & Férfi & Nó & $\begin{array}{c}\text { Teljes } \\
\text { minta }\end{array}$ & Férfi & Nó & $\begin{array}{c}\text { Teljes } \\
\text { minta }\end{array}$ \\
\hline$n$ & 300 & 993 & 1296 & 300 & 993 & 1296 & 300 & 993 & 1296 \\
\hline Átlag & 32,37 & 34,22 & 33,78 & 20,38 & 20,88 & 20,76 & 11,99 & 13,33 & 13,02 \\
\hline SD & 9,82 & 10,40 & 10,3 & 6,19 & 6,15 & 6,17 & 4,43 & 4,91 & 4,84 \\
\hline
\end{tabular}




\section{Megbeszélés}

A tanulmány célja a Bizonytalanságintolerancia Skála 12-tételes verziója (IUS-12; Carleton, Norton és mtsai, 2007) magyar változatának elkészítése és pszichometriai elemzése volt. A téma relevanciáját az adja, hogy a bizonytalanság intoleranciájára való fokozott hajlam különböző szomatikus (pl. hipertónia, emésztési problémák, reumás megbetegedések) és mentális (pl. szorongás, pánikzavar, depresszió) problémákhoz vezethet (Brosschot és mtsai, 2018; Selye, 1951; Yook és mtsai, 2010). A probléma kialakulásához feltehetóen hozzájárulnak az olyan faktorok, mint a túlzott aggodalom, a tartós szorongás és a maladaptív érzelemregulációs stratégiák, amelyek mind jellemző́k a bizonytalanságot rosszul tứrő személyekre (Brosschot és mtsai, 2015; Buhr \& Dugas, 2002; Jaso, Hudiburgh, Heller, \& Timpano, 2020; McDermott, Smith, \& Cougle, 2019; Ouellet és mtsai, 2019). Továbbá a bizonytalanság intoleranciája a szorongásos és a depressziós zavarok esetében transzdiagnosztikus tényezőként játszhat szerepet (Carleton, Mulvogue és mtsai, 2012; Jensen és mtsai, 2016; McEvoy \& Mahoney, 2012; Strout és mtsai, 2018). Ezért fontosnak tartottuk, hogy a Bizonytalanságintolerancia Kérdőív rövid verziója (IUS-12) magyar nyelven is elérhető és használható legyen. A jelen tanulmányban bemutatott pszichometriai elemzés eredményéból kiderül, hogy a magyar nyelvre adaptált változatban is megbízhatóan múködik a kétfaktoros elrendezés; illetve a kérdőív egydimenziós látens struktúrája következtében a skála összpontszáma is használható jövőbeli kutatások és a klinikai gyakorlat során. A modern tesztelméleti elemzés eredményei alapján megállapítható, hogy a kérdőív tételei jól diszkriminálnak a látens változó különböző szintjeivel rendelkező kitöltók között. Ez azt jelenti, hogy az IUS-12 kérdőív magyar mintán is széles körben képes megbízhatóan mérni a bizonytalanság intoleranciáját. Használható átlagos populáción, valamint olyan mintákban is, ahol a kitöltők az átlagosnál sokkal jobban vagy kevésbé túrik a bizonytalanságot. Tehát a kérdőív összességében megfelelően mér meglehetősen nagy szórástartományban.

A kérdőív skálái és összpontszáma az elvártaknak megfeleló irányú öszszefüggést mutatnak rokon pszichológiai jelenségekkel, mint a szorongás, a depresszió és a pszichológiai jóllét (utóbbival fordítottan). A korábbi vizsgálatok eredményei is alátámasztják, hogy a bizonytalanság intoleranciája növeli a szorongásos és a depressziós tünetek valószínúségét és mindezek által hozzájárul a pszichológiai jóllét csökkenéséhez (Carleton, Weeks és mtsai, 2012; Holaway és mtsai, 2006; Jensen és mtsai, 2016; McEvoy \& Mahoney, 2012; Yook és mtsai, 2010). Az eredményeink arra utalhatnak, hogy ez hasonlóan igaz magyar mintán is. Ugyanakkor a nem túl erős együttjárások hátterében állhat, hogy minden mért konstruktum erősen kapcsolódik a neuroticizmus dimenzióhoz (McEvoy \& Mahoney, 2012). 
Előfordulhat, hogy a változók közötti kapcsolat csupán látszólagos, mivel mindegyiket a neuroticizmus határozza meg, amelyet jelen tanulmányban nem mértünk. Ugyanakkor mindez nem von le a mérőeszköz megfelelő konvergens validitásának tényéből, különösen annak fényében, hogy a korábbi vizsgálatok eredményei szerint a neuroticizmus kontrollja mellett is fennáll a szignifikáns lineáris kapcsolat az alacsony bizonytalanságtúrés és a szorongás, illetve a depresszió között (McEvoy \& Mahoney, 2011).

A vizsgált szociodemográfiai háttérváltozók (életkor, nem) szintén összefüggenek a bizonytalanság túrésének képtelenségével. Eredményeink szerint az életkor előrehaladtával csökken a bizonytalanságintolerancia mértéke, amely tendencia ugyan gyenge korrelációs együtthatóban tükröződik, de hasonló mintázatot követ, mint a szorongás (Kessler és mtsai, 2005; Zsido és mtsai, 2020) és szorongásos zavarok (Bandelow és mtsai, 2015; Zsido, Arato, Inhof, Janszky, \& Darnai, 2018) prevalenciájának csökkenéséhez az életkor előrehaladtával. Valamint egybevág a korábbi, hasonló tanulmányok eredményeivel is (Buhr \& Dugas, 2002). A nemi különbséget tekintve azt találtuk, hogy a nők magasabb pontszámot értek el az IUS-12 összpontszám és a gátló szorongás skála esetében, mint a férfiak; bár a hatáserősségek gyengék, a különbség fakadhat a mintánk egyenlőtlen nemi arányából is. Ezzel szemben a prospektív szorongás esetében nem találtunk nemi különbséget. Eredményünk ellentmond az eredeti tanulmányban közölteknek (Carleton, Norton és mtsai, 2007). Ugyanakkor, mivel a nőkre általánosságban jellemzóbb, hogy magasabb pontszámot érnek el az aggodalmat és szorongást mérő skálákon (Bandelow \& Michaelis, 2015; Freeston és mtsai, 1994; Remes, Brayne, Van Der Linde, \& Lafortune, 2016; Robichaud, Dugas, \& Conway, 2003; Zsido és mtsai, 2020), nem meglepó az általunk talált eredmény, és egybevág más, korábbi kutatások eredményeivel (Buhr \& Dugas, 2002) is. Ugyanakkor lehetséges, hogy itt is a neuroticizmus mint háttérváltozó hatása okozza a megfigyelt különbséget. A korábbi vizsgálatokban felvetik annak a lehetőségét is, hogy a maladaptív érzelemregulációs stratégiák állhatnak a nemi különbségek hátterében (Robichaud és mtsai, 2003; Zlomke \& Hahn, 2010).

A biztató eredmények ellenére, mint minden kutatásnak, jelen tanulmánynak is vannak limitációi, amelyeket fontos megemlíteni. Egyrészt, a kitöltők többsége (háromnegyede) nő volt, és mivel találtunk is nemi különbségeket a kérdőíven, ez hatással lehetett az eredmények alakulására. Másrészt, ugyan a vizsgált minta életkori szempontból igen széles körú volt, a jövőben fontos lenne klinikai mintákon (pl. szorongásos vagy hangulatzavarral diagnosztizált páciensek esetében) is vizsgálni a sztenderd pontszámokat és a kérdőív diszkriminatív képességét. Az itt kapott eredmények általánosíthatóságát korlátozza a kényelmi mintavétel alkalmazása, valamint az ok-okozati következtetések levonását nem teszi lehetővé a kutatás keresztmetszeti jellege. 
Összességében az IUS-12 magyar mintán is megbízható és érvényes kérdőív, amely széles körben alkalmazható. Eredményeink egybecsengenek az eredeti verzió esetén és más nemzetközi adaptációs kutatások során kapott eredményekkel, így a mérőeszköz alkalmazása akár a kultúrák közötti öszszehasonlítást is lehetóvé teszi. A bizonytalanság intoleranciája kutatásának és gyakorlatban történő gyors és könnyú mérésének sok pozitív hozadéka lehet. Alkalmazható lehet mentális egészségfejlesztés, prevenció és intervenció hatékonyságának vizsgálata során is. A jövőbeli kutatások során fontos lenne továbbá feltárni, hogy különböző pszichiátriai zavarok jelenléte esetében miként jelenik meg a bizonytalanság intoleranciája, illetve hogy lehet-e szerepe például a különböző fóbiák kialakulásában.

\section{Irodalom}

American Psychological Association (2010). Publication manual of the American Psychological Association, 6th ed. In Publication manual of the American Psychological Association, 6th ed. Washington, DC, US: American Psychological Association

Baker, F.B. (2001). The Basics of Item Response Theory (2nd ed.). College Park, MD: ERIC Clearinghouse on Assessment and Evaluation

Balsamo, M., Cataldi, F., Carlucci, L., \& Fairfield, B. (2018). Assessment of anxiety in older adults: A review of self-report measures. Clinical Interventions in Aging, 13, 573-593.

Bandelow, B., \& Michaelis, S. (2015). Epidemiology of anxiety disorders in the 21st century. Dialogues in Clinical Neuroscience, 17(3), 327-335.

Bandelow, B., Reitt, M., Röver, C., Michaelis, S., Görlich, Y., \& Wedekind, D. (2015). Efficacy of treatments for anxiety disorders. International Clinical Psychopharmacology, 30(4), 183-192.

Bereczkei, T. (2000). Evolutionary psychology: A new perspective in the behavioral sciences. European Psychologist, 5(3), 175-190.

Blom, E. H., Bech, P., Högberg, G., Larsson, J. O., \& Serlachius, E. (2012). Screening for depressed mood in an adolescent psychiatric context by brief self-assessment scales testing psychometric validity of WHO-5 and BDI-6 indices by latent trait analyses. Health and Quality of Life Outcomes, 10:149. DOI: 10.1186/1477-7525-10-149

Brosschot, J.F., Verkuil, B., \& Thayer, J. (2018). Generalized unsafety theory of stress: Unsafe environments and conditions, and the default stress response. International Journal of Environmental Research and Public Health, 15(3), 464. DOI: 10.3390/ijerph15030464

Brosschot, J.F., Verkuil, B., \& Thayer, J.F. (2015). The default response to uncertainty and the importance of perceived safety in anxiety and stress: An evolution-theoretical perspective. Journal of Anxiety Disorders, 41, 22-34.

Browne, M.W., \& Cudeck, R. (1992). Alternative ways of assessing model fit. Sociological Methods and Research, 21(2), 230-258.

Buhr, K., \& Dugas, M.J. (2002). The intolerance of uncertainty scale: Psychometric properties of the English version. Behaviour Research and Therapy, 40(8), 931-945.

Carleton, N.R. (2016). Fear of the unknown: One fear to rule them all? Journal of Anxiety Disorders, 41, 5-21.

Carleton, N.R., Mulvogue, M.K., Thibodeau, M.A., McCabe, R.E., Antony, M.M., \& Asmundson, G.J.G. (2012). Increasingly certain about uncertainty: Intolerance of uncertainty across anxiety and depression. Journal of Anxiety Disorders, 26(3), 468-479. 
Carleton, N.R., Norton, M.A.P.J., \& Asmundson, G.J.G. (2007). Fearing the unknown: A short version of the Intolerance of Uncertainty Scale. Journal of Anxiety Disorders, 21(1), 105-117.

Carleton, N.R., Sharpe, D., \& Asmundson, G.J.G. (2007). Anxiety sensitivity and intolerance of uncertainty: Requisites of the fundamental fears? Behaviour Research and Therapy, 45(10), 2307-2316.

Carleton, N.R., Weeks, J.W., Howell, A.N., Asmundson, G.J.G., Antony, M.M., \& McCabe, R.E. (2012). Assessing the latent structure of the intolerance of uncertainty construct: An initial taxometric analysis. Journal of Anxiety Disorders, 26(1), 150-157.

Chalmers, R.P. (2012). Mirt: A multidimensional item response theory package for the R environment. Journal of Statistical Software, 48(1), 1-29.

Dugas, M.J., Hedayati, M., Karavidas, A., Buhr, K., Francis, K., \& Phillips, N.A. (2005). Intolerance of uncertainty and information processing: Evidence of biased recall and interpretations. Cognitive Therapy and Research, 29(1), 57-70.

Dunn, T.J., Baguley, T., \& Brunsden, V. (2014). From alpha to omega: A practical solution to the pervasive problem of internal consistency estimation. British Journal of Psychology, 105(3), 399-412.

Fergus, T.A. (2013). A comparison of three self-report measures of intolerance of uncertainty: An examination of structure and incremental explanatory power in a community sample. Psychological Assessment, 25(4), 1322-1331.

Freeston, M.H., Rhéaume, J., Letarte, H., Dugas, M.J., \& Ladouceur, R. (1994). Why do people worry? Personality and Individual Differences, 17(6), 791-802.

Gentes, E.L., \& Ruscio, A.M. (2011). A meta-analysis of the relation of intolerance of uncertainty to symptoms of generalized anxiety disorder, major depressive disorder, and obsessive-compulsive disorder. Clinical Psychology Review, 31(6), 923-933.

Greco, V., \& Roger, D. (2003). Uncertainty, stress, and health. Personality and Individual Differences, 34(6), 1057-1068.

Holaway, R.M., Heimberg, R.G., \& Coles, M.E. (2006). A comparison of intolerance of uncertainty in analogue obsessive-compulsive disorder and generalized anxiety disorder. Journal of Anxiety Disorders, 20(2), 158-174.

Hu, L., \& Bentler, P.M. (1998). Fit indices in covariance structure modeling: Sensitivity to underparameterized model misspecification. Psychological Methods, 3(4), 424-453.

Jaso, B.A., Hudiburgh, S.E., Heller, A.S., \& Timpano, K.R. (2020). The relationship between affect intolerance, maladaptive emotion regulation, and psychological symptoms. International Journal of Cognitive Therapy, 13(1), 67-82.

JASP Team (2019). JASP (Version 0.10.2) [Computer software]. Letöltve: 2020. 08. 01-jén: https://jasp-stats.org/

Jensen, D., Cohen, J.N., Mennin, D.S., Fresco, D.M., \& Heimberg, R.G. (2016). Clarifying the unique associations among intolerance of uncertainty, anxiety, and depression. Cognitive Behaviour Therapy, 45(6), 431-444.

Kessler, R.C., Berglund, P., Demler, O., Jin, R., Merikangas, K.R., \& Walters, E.E. (2005). Lifetime prevalence and age-of-onset distributions of DSM-IV disorders in the national comorbidity survey replication. Archives of General Psychiatry, 62(6), 593-602.

Khawaja, N.G., \& Yu, L.N.H. (2010). A comparison of the 27-item and 12-item intolerance of uncertainty scales. Clinical Psychologist, 14(3), 97-106.

LeDoux, J.E. (2012). Rethinking the Emotional Brain. Neuron, 73(4), 653-676.

LeDoux, J.E., \& Daw, N.D. (2018). Surviving threats: Neural circuit and computational implications of a new taxonomy of defensive behaviour. Nature Reviews Neuroscience, 19(5), 269-282.

Li, C.H. (2016). The performance of ML, DWLS, and ULS estimation with robust corrections in structural equation models with ordinal variables. Psychological Methods, 21(3), 369-387. 
Marks, I., \& Nesse, R.M. (1994). Fear and fitness: An evolutionary analysis of anxiety disorders. Ethology and Sociobiology, 15(5-6), 247-261.

McDermott, K.A., Smith, H.L., \& Cougle, J.R. (2019). An examination of perseverative thinking and perception of threat from emotion as mechanisms underlying the relationship between distress intolerance and internalizing symptoms. Cognitive Therapy and Research, 43(3), 561-569.

McEvoy, P.M., \& Mahoney, A.E.J. (2011). Achieving certainty about the structure of intolerance of uncertainty in a treatment-seeking sample with anxiety and depression. Journal of Anxiety Disorders, 25(1), 112-122.

McEvoy, P.M., \& Mahoney, A.E.J. (2012). To be sure, to be sure: Intolerance of uncertainty mediates symptoms of various anxiety disorders and depression. Behavior Therapy, 43(3), 533-545.

Mueller, A.E., Segal, D.L., Gavett, B., Marty, M.A., Yochim, B., June, A., et al. (2015). Geriatric Anxiety Scale: Item response theory analysis, differential item functioning, and creation of a ten-item short form (GAS-10). International Psychogeriatrics, 27(7), 1099-1111.

Nesse, R.M. (2005). Natural selection and the regulation of defenses. A signal detection analysis of the smoke detector principle. Evolution and Human Behavior, 26(1), 88-105.

Ouellet, C., Langlois, F., Provencher, M.D., \& Gosselin, P. (2019). Intolerance of uncertainty and difficulties in emotion regulation: Proposal for an integrative model of generalized anxiety disorder. Revue Europeenne de Psychologie Appliquee, 69(1), 9-18.

Radnóti, I. (2014). A vállalkozói kockázatokhoz való viszonyulás közgazdasági föiskolai hallgatók és kisvállalkozók körében. PhD-értekezés. Budapest: Eötvös Loránd Tudományegyetem. Letöltve: 2019. május 11-én: https:/ / ppk.elte.hu/file/radnoti_istvan_disszertacio.pdf

Remes, O., Brayne, C., Van Der Linde, R., \& Lafortune, L. (2016). A systematic review of reviews on the prevalence of anxiety disorders in adult populations. Brain and Behavior, 6(7): e00497. DOI: 10.1002/brb3.497

Robichaud, M., Dugas, M.J., \& Conway, M. (2003). Gender differences in worry and associated cognitive-behavioral variables. Journal of Anxiety Disorders, 17(5), 501-516.

Rozgonjuk, D., Elhai, J.D., Täht, K., Vassil, K., Levine, J.C., \& Asmundson, G.J.G. (2019). Non-social smartphone use mediates the relationship between intolerance of uncertainty and problematic smartphone use: Evidence from a repeated-measures study. Computers in Human Behavior, 96, 56-62.

Rózsa, S., Szádóczky, E., \& Füredi, J. (2001). A Beck Depresszió Kérdőív rövidített változatának jellemzői a hazai mintán. Psychiatria Hungarica, 16(4), 379-397.

Samejima, F. (1968). Estimation of latent ability using a response pattern of graded scores. ETS Research Bulletin Series, 1968(1), 1-169.

Selye, H. (1946). The general adaptation syndrome and the diseases of adaptation. The Journal of Clinical Endocrinology and Metabolism, 6(2), 117-230.

Selye, H. (1951). The General-Adaptation-Syndrome. Annual Review of Medicine, 2(1), 327342.

Strout, T.D., Hillen, M., Gutheil, C., Anderson, E., Hutchinson, R., Ward, H., et al. (2018). Tolerance of uncertainty: A systematic review of health and healthcare-related outcomes. Patient Education and Counseling, 101(9), 1518-1537.

Susánszky, É., Konkoly Thege, B., Stauder, A., \& Kopp, M. (2006). A WHO Jól-Lét Kérdőív rövidített (WBI-5) magyar változatának validálása a Hungarostudy 2002 országos lakossági egészségfelmérés alapján. Mentálhigiéné és Pszichoszomatika, 7(3), 247-255.

Tiego, J., Oostermeijer, S., Prochazkova, L., Parkes, L., Dawson, A., Youssef, G., et al. (2019). Overlapping dimensional phenotypes of impulsivity and compulsivity explain cooccurrence of addictive and related behaviors. CNS Spectrums, 24(4), 426-440. 
Topp, C.W., Østergaard, S.D., Søndergaard, S., \& Bech, P. (2015). The WHO-5 well-being index: A systematic review of the literature. Psychotherapy and Psychosomatics, 84(3), 167-176.

Yook, K., Kim, K.H., Suh, S.Y., \& Lee, K.S. (2010). Intolerance of uncertainty, worry, and rumination in major depressive disorder and generalized anxiety disorder. Journal of Anxiety Disorders, 24(6), 623-628.

Zlomke, K.R., \& Hahn, K.S. (2010). Cognitive emotion regulation strategies: Gender differences and associations to worry. Personality and Individual Differences, 48(4), 408413.

Zsido, A.N. (2019). A fenyegető ingerek hatására fellépő figyelmi torzítások és változások a fenntartott figyelmi folyamatokban: Áttekintés. Magyar Pszichologiai Szemle, 74(2), 233-255.

Zsido, A.N., Arato, N., Inhof, O., Janszky, J., \& Darnai, G. (2018). Short versions of two specific phobia measures: The snake and the spider questionnaires. Journal of Anxiety Disorders, 54, 11-16.

Zsido, A.N., Teleki, S.A., Csokasi, K., Rozsa, S., \& Bandi, S.A. (2020). Development of the short version of the spielberger state-trait anxiety inventory. Psychiatry Research, 291, 113223. DOI: $10.1016 /$ j.psychres.2020.113223

\section{Anyagi támogatás}

A kutatás az EFOP-3.6.1-16-2016-00004 „Átfogó fejlesztések a Pécsi Tudományegyetemen az intelligens szakosodás megvalósítása érdekében" pályázat támogatásával készül. Az innovációs és technológiai minisztérium ÚNKP-20-4 kódszámú Új Nemzeti Kiválóság Programjának a Nemzeti Kutatási, Fejlesztési és Innovációs Alapból finanszírozott szakmai támogatásával készült.

\section{Szerzói munkamegosztás}

Kutatási ötlet - AN, LB; a módszertan kidolgozása - ZSNA, AN, IO, BT, STD, LB; a mérőeszközök összegyuujtése és a felmérés elkészítése - AN, IO, BT, STD; adatgyuujtés - IO, BT, STD; az adatok rendezése - ZSNA, AN, IO; statisztikai analízis - ZSNA, AN, LB; szupervízió - ZSNA, LB; a kézirat elkészítése - ZSNA, AN, IO, BT, STD, LB. A cikk végleges változatát valamennyi szerző elolvasta és jóváhagyta.

\section{Érdekeltségek}

A szerzők ezúton kijelentik, hogy esetükben nem állnak fenn érdekütközések. 


\section{Függelék: A Bizonytalanságintolerancia Skála (Intolerance of Uncertainty, IUS-12) magyar változata, kitöltési instrukciója és kiértékelési útmutatója}

\section{IUS-12}

Az alábbi kérdőívben olyan állításokat talál, amelyek azt írják le, miként reagálnak az emberek a mindennapokban előforduló bizonytalanságokra. Kérjük, az alábbi skála segítségével jelölje be, melyik állítással mennyire ért egyet/mennyire jellemző önre!

1 = egyáltalán nem ért egyet/jellemző

3 = valamennyire egyetért/jellemző

5 = teljes mértékben egyetért/jellemző

\begin{tabular}{|l|l|l|l|l|l|}
\hline 1. Nagyon kiborítanak a váratlan események. & 1 & 2 & 3 & 4 & 5 \\
\hline $\begin{array}{l}\text { 2. Nagyon frusztrál, ha nem áll rendelkezésemre minden } \\
\text { információ, amire szükségem van. }\end{array}$ & 1 & 2 & 3 & 4 & 5 \\
\hline 3. Bizonytalanságban nem tudok teljes életet élni. & 1 & 2 & 3 & 4 & 5 \\
\hline $\begin{array}{l}\text { 4. Az embernek mindig előre kell tekintenie, hogy elkerülhesse } \\
\text { a meglepetéseket. }\end{array}$ & 1 & 2 & 3 & 4 & 5 \\
\hline $\begin{array}{l}\text { 5. Egy apró elöre láthatatlan esemény még a legjobb tervezés } \\
\text { mellett is mindent tönkretehet. }\end{array}$ & 1 & 2 & 3 & 4 & 5 \\
\hline 6. Amikor eljön a cselekvés ideje, a bizonytalanság megbénít & 1 & 2 & 3 & 4 & 5 \\
\hline 7. Amikor bizonytalan vagyok, nem tudok nagyon jól teljesíteni. & 1 & 2 & 3 & 4 & 5 \\
\hline 8. Mindig tudni akarom, mit tartogat számomra a jövő. & 1 & 2 & 3 & 4 & 5 \\
\hline 9. Ki nem állhatom a meglepetéseket. & 1 & 2 & 3 & 4 & 5 \\
\hline 10. A legkisebb kétség megakaszthat a cselekvésben. & 1 & 2 & 3 & 4 & 5 \\
\hline 11. Mindent meg kéne tudnom tervezni előre. & 1 & 2 & 3 & 4 & 5 \\
\hline 12. Muszáj elkerülnöm minden bizonytalan helyzetet. & 1 & 2 & 3 & 4 & 5 \\
\hline
\end{tabular}

\section{Skálaképzési útmutató:}

Forditott tétel nincs.

Prospektív szorongás skála: az 1., 2., 4., 5., 8., 9. és 11. tételekre adott pontszám összege.

Gátló szorongás skála: a 3., 6., 7., 10. és 12. tételekre adott pontszám összege. Összpontszám: mind a 12 tételre adott pontszám összege. 


\title{
Hungarian Adaptation of the short version of the Intolerance of Uncertainty Scale
}

\author{
ZSIDÓ, N. ANDRÁS - ARATÓ, NIKOLETT - INHÓF, ORSOLYA - \\ BUDAI, TIMEA - STECINA, T. DIÁNA - LABADI, BEATRIX
}

Introduction: Intolerance of uncertainty refers to an individual's fundamental inability to tolerate the occurrence of negative events as well as the unpredictability of such events. The resulting constant stress and excessive worry can lead to severe physical and mental problems. Previous studies suggest that it can serve as the root of anxiety and depressionrelated psychiatric disorders. Aim: The aim of the present study was to present the psychometric properties of the short version of the Intolerance of Uncertainty Scale in a sufficiently large and age-diverse Hungarian sample. Method: A total of 1297 respondents (300 men and 993 women, 4 chose not to answer) completed the survey. The mean age of the participants was 44.63 years $(\mathrm{SD}=22.44$ years; range $=18-83$ years). In addition to the Intolerance of Uncertainty Scale, participants completed the World Health Organization Well-Being Index, and the short versions of the Beck Depression Inventory, and the Spielberger Trait Anxiety Scale. The psychometric properties of the shortened Intolerance of Uncertainty Scale were tested using classical and modern test theory methods. Results: The shortened Intolerance of Uncertainty Scale has appropriate psychometric indicators on a Hungarian sample (McDonald's $\omega=0.82$ and 0.84 ). The items of the questionnaire discriminated well between respondents with different levels of the latent variable, and the questionnaire measured well over a large deviation of scores $( \pm 2 \mathrm{SD})$; thus, it is able to provide information on the ability to tolerate uncertainty in approximately $95 \%$ of the population. The subscales and total score of the questionnaire correlated with related constructs as we previously expected, for instance anxiety $(r=0.22-0.36, p<0.001)$ and depression $(r=0.26-0.40, p<0.001)$. Conclusions: Overall, the short version of the Intolerance of Uncertainty Scale is also a reliable and valid questionnaire for the Hungarian sample. It can be used for efficacy testing of mental health promotion, anxiety and depression prevention, or therapeutic intervention.

Keywords: uncertainty tolerance, Intolerance of Uncertainty Scale, IUS, psychometric analysis, anxiety, depression

A cikk a Creative Commons Attribution 4.0 International License (https:/ / creativecommons.org/ licenses/by/4.0/) feltételei szerint publikált Open Access közlemény, melynek szellemében a cikk bármilyen médiumban szabadon felhasználható, megosztható és újraközölhető, feltéve, hogy az eredeti szerző és a közlés helye, illetve a CC License linkje és az esetlegesen végrehajtott módosítások feltüntetésre kerülnek. (SID_1) 